\title{
2000-2015 Yılları Arasında Değer Eğitimi Üzerine Yapılan Doktora Tezlerinin İçerik Analizi
}

\author{
Mevlüt GÜNDÜZ ${ }^{1}$, Zuhal BAŞPINAR ${ }^{2}$, Ayşegül BÜYÜKKARCI ${ }^{3}$ \\ ${ }^{1}$ Yrd. Doç. Dr., Süleyman Demirel Üniversitesi Temel Eğitim Bölümü,mevlutounduz@sdu.edu.tr \\ ${ }^{2}$ Arş.Gör. Süleyman Demirel Üniversitesi Temel Eğitim Bölümü, zubalbaspinar@,sdu.edu.tr \\ ${ }^{3}$ Arş.Gör. Süleyman Demirel Üniversitesi Temel Eğitim Bölümü, aysegulbujuk.karci@sdu.edu.tr
}

\section{DOI: http://dx.doi.org/10.14582/DUZGEF.1817}

\section{ÖZ}

Bu çalışma, değer eğitimi üzerine yapılan doktora tezlerine ait bir içerik analizidir. Bu amaçla 2000-2015 yılları arasında, YÖK tez sayfasından ulaşılabilen 54 doktora tezi incelenmiştir. İlgili tezleri değerlendirmek için araştırmacı tarafından geliştirilen yayın sınıflama formu geliştirilmiştir. Her bir tez bu form yardımıyla içerik analizine tabi tutulmuş ve tezlere ait veriler bir veri tabanına kaydedilmiştir. Veri tabanından alınan veriler SPSS 22.0 programı kullanılarak analiz edilmiştir. Sonuçlar grafik, frekans ve yüzde olarak betimsel biçimde sunulmuştur. Çalışma sonucunda değer eğitimi üzerine yapılan doktora tezlerinde 2009 yılından itibaren büyük bir artışın yaşandığı, Gazi Üniversitesi'nin değer eğitimi üzerine en çok doktora tezi yaptıran üniversite olduğu, örneklem olarak daha çok ilköğretim öğrencilerinin alındığ1, karma yöntemin daha çok kullanıldığı, veri toplama aracı olarak ölçek ve görüşme formunun çok kullanıldığı, konu olarak ise daha çok öğretim programındaki değerler ve doğrudan bir değer üzerine yapılan çalışmaların olduğu tespit edilmiştir.

Anahtar Kelimeler: Değer, Değer eğitimi, İçerik analizi, Doktora tezi, Araştırma sonuçları

\section{Content Analysis of Doctoral Theses on Values Education Published between}

\section{0 and 2015}

\begin{abstract}
This study is a content analysis of doctoral theses on values education. For this purpose, 54 doctoral theses, published between 2000 and 2015, which can be reached from thesis database of Council of Higher Education, were analyzed. A publication classification form was developed by the researcher to evaluate the relevant theses. Each thesis was analyzed by content analysis method through this form and the data belonging to thesis were saved in a database. Data gathered from the database were analyzed using SPSS 22.0 program. The results were presented in graphical format, by showing frequencies and percentages in a descriptive way. As a result of the study, a great increase was observed in the doctoral theses on values education since 2009, it was found out that Gazi University has the highest number of doctoral dissertations on values education, mostly primary school students were taken as samples in those studies, the studies were designed mostly in mixed methodology, and that interview forms and scales were used extensively to collect data, and as research topics, values in curriculum were studied mostly, and also it is possible to find studies on just one values directly.
\end{abstract}

Keywords: Value, Value education, Content analysis, Doctoral dissertation, Research results

\section{GİRİ̧̧}

Toplumun bir arada yaşaması ve güven ortamının oluşmasında değer eğitimi önemli bir yere sahiptir. Bu açıdan değer eğitimi üzerine yapılan çalışmalar son yıllarda önemini artırmaya başlamıştır (Gündüz, 2014; Ülger, 2012; Tahiroğlu, 2011; Çengelci, 2010; Yiğittir, 2009; Aladağ, 2009; Keskin, 2008; Ulusoy, 2007; Dilmaç, 2007; Akbaş, 2004). Özelliklede değer eğitimine ne zaman başlanmalı, değerler nerede öğretilmeli, değer öğretiminde kime daha çok görev düşüyor (Özdaş, 2013), resmi program yeterli mi yoksa örtük programa ihtiyaç var mı? (Baysal, 2013), gibi konular değer eğitimi üzerine araştırma yapan kişilerin merak konusu olmuştur.

Değer kavramı Latince "valere" kökünden türemiş ve "değerli olma" anlamına gelmekle birlikte Znaniecki tarafından literatüre kazandırılmıştır (Bilgin, 1995). Değer genel olarak, bir nesneye, varlı̆ga ya da faaliyete, ruhsal, ahlaksal ve toplumsal açıdan ya da estetik yönden tanınan önem ya da üstünlük derecesi’ (Öncül, 2000,s.281) olarak tanımlanmaktadır. Milletler kültürlerinden etkilenerek kendi değerlerini oluştururlar 
ve bu değerleri korumak isterler. Değerler kişilerin ve dolayısıyla toplumların nasıl yaşayacağını belirler. Değerler toplumun devamlılığını sağlayan ve gelecek nesillere 1şık tutan olgulardır. Bu yüzden sağlıklı nesiller yetiştirmek için değerlerin doğru ve etkili olarak öğretilmesi gerekir (Özsoy, 2007; Kantar, 2014).

Değerlerin toplum açısından işlevlerini, Fichter (1990) şu şekilde ifade etmektedir:

- Değerler, kişilerin ve birlikteliklerin sosyal değerinin yargılanmasında hazır birer araç olarak kullanılır.

- Değerler, kişilerin dikkatini; istenilir, yararlı ve önemli olarak görülen maddî kültür nesneleri üzerinde odaklar.

- Her toplumdaki ideal düşünme ve davranma yollarına, değerler tarafından işaret edilir.

- Değerler, kişilerin sosyal rollerini seçmesinde ve gerçekleştirmesinde rehberlik eder.

- Değerler, sosyal kontrol ve baskının araçlarıdır. Kişileri törelere uymaya yöneltir, doğru şeyleri yapmaya yüreklendirir.

- Değerler, dayanışma araçları olarak da işlevde bulunur. Sosyal bilimlerin aksiyonlarından biri de, grupların yüksek düzeyde bazı değerlerin paylaşılması amacıyla buluştuğudur (s.231-232’den akt., Özensel, 2003).

Değerleri içerik ve muhteva açısından nesne değerleri (hoş, yararlı, kullanışlı), mantıksal açıdan (doğru), ahlaki yönden (iyi), sanat açısından (güzel) olarak" tasniflemek mümkündür (Bolay, 2013,s.76). Örneğin Spranger (1928), (akt., Ekşi ve Katılmış, 2011) kapsam alanına uygun olarak değerleri; Bilimsel, ekonomik, estetik, sosyal, politik ve dini değerlerler olarak sınıflandırmıştır. Literatürdeki diğer sınıflamalar ise şöyledir:

Lickona (1991), değerleri ahlaki ve ahlaki olmayan değerler olarak; Rokeach (1973) amaç ve araç değerler olmak üzere ikiye ayırmıştır. Schwartz (1992) değerleri, güç, başarı, yaşamdan haz duyma, uyarım, öz yönelim, evrensellik, iyilikseverlik, geleneksellik, uyma ve güvenlik olarak, Nelson (1974) bireysel, grup ve sosyal değerler olarak (akt., Naylor ve Diem,1987) sınıflandırmıştır. Güngör (1998) değerleri estetik, teorik, iktisadi, siyasi, sosyal ve dinî değerler olarak; Kale (2004) evrensel ve kültürel olarak, Ercan (2001) ulusal ve evrensel değerler olarak, Canatan (2004) geleneksel ve modern değerler olarak sınıflamıştır. Acat ve Aslan (2012) ise muhafazakâr-geleneksel, ulusal-milli, öze dönük-kişisel, sosyal-toplumsal, bilimsel-yenilikçi olarak; Gündüz’de (2016) içe ve dışa dönük değerler olarak sınıflama yapmıştır.

Değerlerin tüm insanlar tarafindan benimsenmesi ve değerlere gereken önemin verilmesi, değer eğitimini her geçen gün daha önemli hale getirmekte ve araştırmacıların dikkatini çekmektedir. Gün geçtikçe araştırmacılarında daha derinlemesine değer eğitimi araştırmaları yapmaları konunun önemine dikkat çekmektedir. Son yıllarda değer eğitimi üzerine yapılan araştırmalara baktığımızda dikkat çekici bir gelişme olduğunu söyleyebiliriz (Gündüz, 2014). Ancak değer eğitimi üzerine yapılan çalışmaların gittikçe artması önemli bir gelişme olmakla birlikte, karışıklığa da neden olabilmektedir. Bu bağlamda yapılan çalışmaların daha düzenli hale getirilmesi ve birleştirilmesi gerekir. Bu çalışma, bundan sonra değerler eğitimi üzerine yapılacak çalışmalara yön vererek, çalısılmayan alanların daha da netleşmesi için tespit niteliği taşıyacağı düşünülmektedir. $\mathrm{Bu}$ alanın gelişmesi ve toplum için önemli bir yeri olan değerlerin gelecek nesillere daha sağlıklı aktarılması için daha bilinçli çalışmaların yapılması ve duyarlılık kazanılması açısından ayrıca önem arz etmektedir.

Değerler eğitiminin son ylllarda büyük bir ilgi görmesinin diğer nedenlerinden biri de toplumsal değerlerinin gittikçe zarar görmesi ve değerlerimizi kaybetmeye başlamamız olabilir. Bilim, sanayi ve teknolojideki hızlı gelişmeler sosyo-kültürel bozulmalara neden olmakla birlikte toplumda cinayet, hırsızlık, terör, tecavüz, uyuşturucu kullanımı, intihar gibi olaylar daha fazla gözlenmeye başlanmıştır (Lickona, 1991). Değerler sosyal hayatın dinamiklerini oluşturmakla beraber aynı zamanda lokomotif görevi de görür. Böylesine önemli bir olguyu yeni nesillere aktarmak ise okul programlarının ve eğitimcilerin önemli görevleri vardır (Akarsu, 2015). Aileler ve eğitimciler ise bu durumun aşılmasını etkili bir değer eğitiminin verilmesi ile olacağını düşünmektedirler (Tilmann, 2000).

Değer eğitimine gereken önemin verilmesi ile ilgili yapılan bazı araştırmalarda; Öğretmen yetiştiren kurumların programlarına değer eğitimi ve temel değerlerin kazandırılması ile ilgili yeni amaçlar konulması, sınıf yönetimi ve değer öğretimi konularında öğretmenlerin kendilerini sürekli geliştirmesi, sınıf öğretmenlerine öğrenci davranışlanının niteliği ve yönetimi, değer eğitimi ve yeni ilköğretim programı ile ilgili hizmet içi 
seminerlerinin verilmesi (Ada, Baysal ve Korucu, 2005), değerler eğitiminin etkili olması için öğretmen ve sistemin sorgulanması gerektiği, öğretmenin kişiliği, bilgisi, memnuniyeti, ilişkileri, değerleri, pedagojik kalitesi ve kısaca öğretmenlik mesleğinin yeniden ele alınması, bu konular üzerine araştırmalar yapılması ve irdelenmesi (Lovat, 2007), değerler eğitiminin takibinde öğretmenlerin, okulun ve sistemlerin merkezde olması ve birlikte hareket etmesi gerektiği (Bryk ve Schneider, 2002), değerler eğitiminin sınıfta, okulda ve toplumda öğretilmesine yönelik çalışmaların yapılması gerektiği (Refshauge, 2004), değerler eğitiminde okuldan daha önemli daha elverişli bir yerin olmadığı (Snook, 2007) vurgulanmaktadır.

Değer eğitimi alanında yapılan bilimsel çalışmaların sayısı artmakla birlikte, düzensiz bir yı̆̆ın oluşturmaya başladığı da söylenebilir. Bu yığını anlamlı hale getirmek için içerik analizi yöntemi kullanılmaya başlanmıştır. Bu gibi nedenlerden ötürü çalışmanın amacı, 2000-2015 yılları arasında değer eğitimi üzerine yapılan doktora tezlerinin içerik analizini yapmak ve bundan sonra yapılacak çalışmaların daha bilimsel ve nitelikli yapılabilmesine yardımcı olmaktır. Bu amaca ulaşmak için ise aşağıdaki sorulara cevap aranmıştır.

- Değer eğitimine yönelik yapılan doktora tezlerinin yıllara göre dağılımı nasıldır?

- Değer eğitimine yönelik yapılan doktora tezlerinin üniversitelere göre dağılımı nasıldır?

- Değer eğitimine yönelik yapılan doktora tezlerinin örneklem türlerine göre dağılımı nasıldır?

- Değer eğitimine yönelik yapılan doktora tezlerinin örneklem büyüklüğüne göre dağılımı nasıldır?

- Değer eğitimine yönelik yapılan doktora tezlerinin kullanılan yöntem türüne göre dağılımı nasıldır?

- Değer eğitimine yönelik yapılan doktora tezlerinin çalışılan konulara göre dağılımı nasıldır?

- Değer eğitimine yönelik yapılan doktora tezlerinin veri toplama tekniklerine göre dağılımı nasıldır?

- Değer eğitimine yönelik yapılan doktora tezlerinin veri analiz tekniklerine göre dağılımı nasıldır?

\section{YÖNTEM}

\subsection{Araştırma Deseni}

$\mathrm{Bu}$ araştırma nitel araştırma yöntemlerinden doküman incelemesi kullanılarak gerçekleştirilmiştir. Dokümanlar nitel araştırmalarda önemli bir veri kaynağıdır ve hem özel hem de resmi dokümanları içerebilir (Creswell, 2005,s.219). Bu araştırmada incelenen dokümanlar araştırmanın amacına uygun olarak 2000-2015 yılları arasında değerler eğitimi alanında yapılan doktora tezleridir.

\subsection{Veri Toplama}

Veriler toplanırken Yök’ün Ulusal Tez Merkezinden ulaşılabilir olan Eğitim- Öğretim alanındaki Türkçe tezler dikkate alınmışır. Erişime açık olmayan tezler ise araştırmaya dahil edilmemiştir. Tezler taranırken değer, değer eğitimi, demokrasi, demokratik değerler, insani değerler, duyuşsal boyut, programdaki değerler gibi anahtar kelimeler kullanılmıştır.

$\mathrm{Bu}$ araştırmada, değer eğitimi alanında yapılan doktora tezlerini incelemek ve içerik analizi yapmak için veri toplama aracı olarak araştırmacı tarafından geliştirilen yayın sınıflama formu kullanılmıştır. Yayın sınıflama formu; tezin kimliği hakkında tanımlayıcı bilgi, tezin konusu, örneklemi, yöntemi, veri toplama aracı ve veri analiz yöntemi gibi bölümlerden oluşmaktadır. Araştırmada kullanılan veri toplama aracının güvenirliği Miles ve Huberman formülü kullanılarak tespit edilmiştir. Araştırmanın güvenirliğini sağlamak amacıyla 4 uzman görüşüne başvurulmuştur. Bu işlemde araştırmacı ve uzman aynı temayı işaretlerse veya her ikisi de aynı temayı işaretlemezlerse bu durum uzmanlar arasında görüş birliği olarak kabul edilmekte; eğer araştırmacı ve uzman farklı temaları işaretlerse bu durum görüş ayrılı̆̆ı olarak kabul edilmektedir (Miles \& Huberman, 1994). Araştırmanın güvenilirliği ise Güvenirlik=Görüş Birliği / (Görüş Birliği + Görüş Ayrllı̆ı) formülü sonucunda en az \%70 düzeyinde güvenilirlik katsayısı ile ortaya konmaktadır (Miles \& Huberman, 1994). Bu araştırmaya Özgü olarak gerçekleştirilen güvenirlik çalışmasında \%92 oranında bir uzlaşma (güvenirlik) sağlanmıştır.

\subsection{Verilerin Analizi}

Değer eğitimi araştırmaları için uyarlanan yayın sınıflama formu sayesinde elde edilen veriler bir veri tabanına kaydedilmiştir. Veri tabanından alınan veriler SPSS 22,0 programı kullanılarak analiz edilmiştir. Bu çalışmada amacımıza uygun olduğu düşünülen içerik analizi yöntemi kullanılmıştır. Çünkü içerik analizi birbirine benzeyen verileri belirli kavramlar ve temalar çerçevesinde bir araya getirmek ve bunları okuyucunun 
anlayabileceği bir biçimde düzenleyerek yorumlamaktır (Yıldırım ve Şimşek, 2006). İçerik analizi, belirli kurallara dayalı kodlamalarla bir metinin bazı sözcüklerinin daha küçük içerik kategorileri ile özetlendiği sistematik, yinelenebilir bir tekniktir (Büyüköztürk, Çakmak, Akgün, Karadeniz ve Demirel, 2009).

\section{BULGULAR}

Araştırmanın bulguları araştırma soruları temel alınarak analiz edilmiştir. İlk problem sorusuna göre değer eğitimi üzerine yapılan doktora tezlerinin yıllara göre dağılımı incelenmiştir.

Tablo 1.Değer Eğitimi Üzerine 2000-2015 Yıllarında Yapılan Doktora Tezlerinin Sayısal Dağılımı

\begin{tabular}{lrr}
\hline Y1l & Frekans & Yüzde \\
\hline 2003 & 2 & 3,7 \\
\hline 2004 & 1 & 1,9 \\
\hline 2006 & 2 & 3,7 \\
\hline 2007 & 3 & 5,6 \\
\hline 2008 & 2 & 3,7 \\
\hline 2009 & 5 & 9,3 \\
\hline 2010 & 7 & 13,0 \\
\hline 2011 & 4 & 7,4 \\
\hline 2012 & 8 & 14,8 \\
\hline 2013 & 9 & 16,7 \\
\hline 2014 & 2 & 3,7 \\
\hline 2015 & 9 & 16,7 \\
\hline
\end{tabular}

Değer eğitimi üzerine Türkiye'de yapılan araştırmalar oldukça yeni olmakla beraber bu çalş̧mada yıl aralığı 2000 ve 2015 olarak belirlenmiştir. 2003 ve 2009 yılları arasında yapılan çalışmaların sayısının az olduğu bariz bir şekilde görülmektedir. 2009 yllından sonra ise çalışmaların sayısında gözle görülür bir artış gözlemlenmiştir. 2014 yllında ise belirgin bir azalış olmakla birlikte, 2015 yllında ise tekrar bir artış görülmeye başlanmıştır. Değer eğitimi üzerine yapılan çalışmalar \%16,7 oranla en fazla 2013 ve 2015 yıllarında olmuştur. En az ise \%3,7 oranla 2003 ve 2014 yıllarında olmuştur. 2005 yılında ise hiçbir tez yapılmamıştır. Bu analizler sonucunda, değer eğitimi üzerine yapılan doktora tezlerinin genellikle son yıllarda ciddi bir artışa geçtiğini söyleyebiliriz. Belli zaman dilimlerinde azalmış olsa da konunun önemi gün geçtikçe araştırmacıların dikkatini daha çok çekmeye başlamıştır.

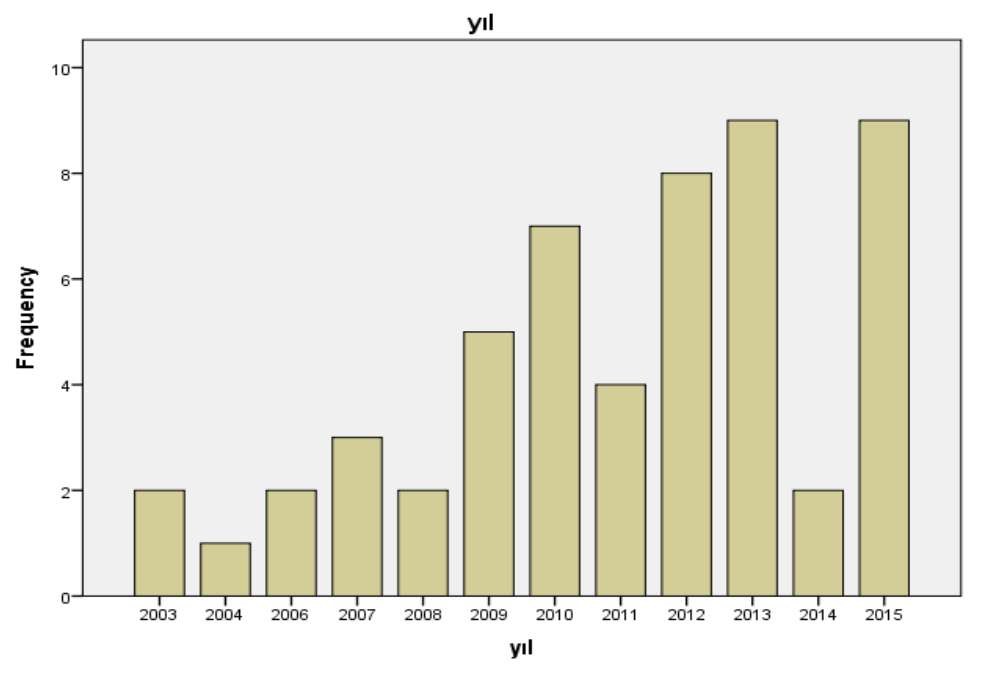

Şekil 1. Doktora tezlerinin ylllara göre dağıllım grafiği 
Tablo 2. Değer Eğitimi Alanında 2000-2015 Yllları Arasında Yapılan Doktora Tezlerinin Üniversitelere Göre Dağıllımı

\begin{tabular}{lrr}
\hline Üniversite & Frekans & Yüzde \\
\hline Abant İzzet Baysal Üniversitesi & 3 & 5,6 \\
\hline Anadolu Üniversitesi & 2 & 3,7 \\
\hline Ankara Üniversitesi & 4 & 7,4 \\
\hline Atatürk Üniversitesi & 5 & 9,3 \\
\hline Çanakkale On Sekiz Mart Üniversitesi & 1 & 1,9 \\
\hline Dokuz Eylül Üniversitesi & 1 & 1,9 \\
\hline Fırat Üniversitesi & 1 & 1,9 \\
\hline Gazi Üniversitesi & 13 & 24,1 \\
\hline Gaziantep Üniversitesi & 2 & 3,7 \\
\hline Hacettepe Üniversitesi & 5 & 9,3 \\
\hline İnönü Üniversitesi & 3 & 5,6 \\
\hline İstanbul Üniversitesi & 1 & 1,9 \\
\hline Kocaeli Üniversitesi & 1 & 1,9 \\
\hline Marmara Üniversitesi & 3 & 5,6 \\
\hline Mersin Üniversitesi & 1 & 1,9 \\
\hline Necmettin Erbakan Üniversitesi & 1 & 1,9 \\
\hline Sakarya Üniversitesi & 1 & 1,9 \\
\hline Selçuk Üniversitesi & 5 & 9,3 \\
\hline Uludağ Üniversitesi & 1 & 1,9 \\
\hline
\end{tabular}

Çalışmada, Türkiye'deki tüm üniversiteler örnekleme dâhil edilmiştir. Literatür taramasında bu alanda çalışmış 19 üniversite olduğu gözlemlenmiştir. Tablo 2 yorumlandığında, ilk dikkat çeken bulgu ise bu alanda çalışma yapmış üniversitelerin azlığıdır. Türkiye'de özel, devlet ve vakıf üniversiteleri dâhil olmak üzere toplam 200’e yakın üniversite bulunmaktadır. Şekle baktığımızda bu alanda çalışma yapmış sadece 19 üniversite olduğu gözlemlenmiştir. En çok çalışma yapan üniversite ise \%24,1 oranla Gazi Üniversitesidir. En az çalışma yapılan üniversiteler ise; Çanakkale On Sekiz Mart, Dokuz Eylül, Firat, İstanbul, Kocaeli, Mersin, Necmettin Erbakan, Sakarya ve Uludağ Üniversiteleridir. Bu anlamda diğer üniversitelerdeki araştırmacıların da bu konuya daha çok eğilmeleri gerektiği söylenebilir.

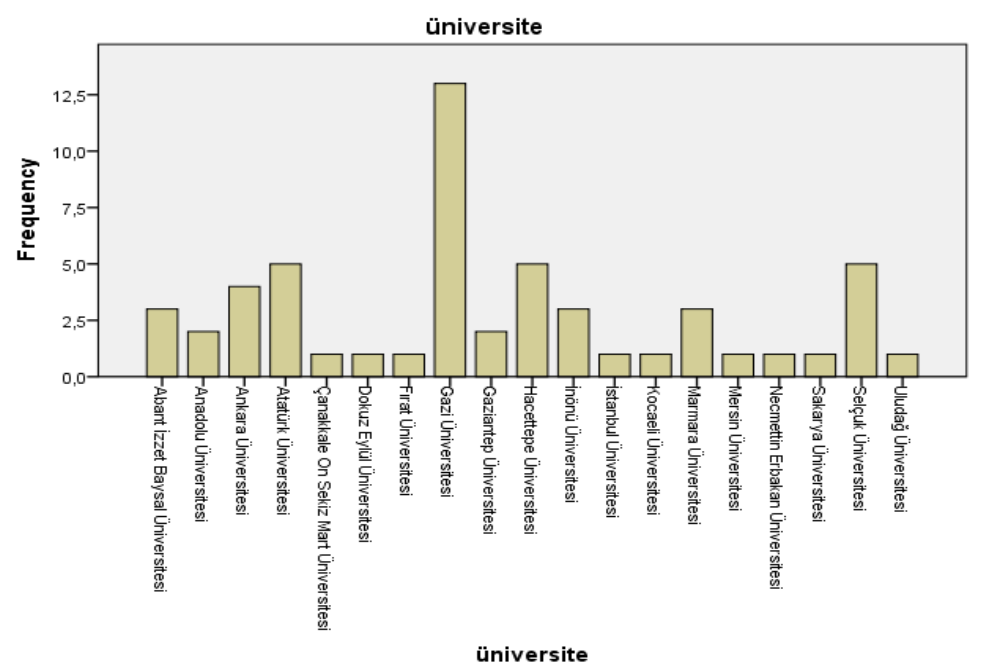

Şekil 2. Doktora tezlerinin üniversitelere göre dağllım grafiği 
Tablo 3. Değer Eğitimi Alanında 2000-2015 Yılları Arasında Yapılan Doktora Tezlerinin Örneklem Türüne Göre Dağılımı

\begin{tabular}{lrr}
\hline Örneklem Türü & Frekans & Yüzde \\
\hline İlköğretim - öğrenci & 23 & 42,6 \\
\hline Ortaokul- öğretmen & 2 & 3,7 \\
\hline Anasınıf1- anne & 1 & 1,9 \\
\hline Anaokulu-öğrenci-anne & 1 & 1,9 \\
\hline İlkögretim- öğrenci- öğretmen-veli-personel & 1 & 1,9 \\
\hline Ö̆gretmen & 2 & 3,7 \\
\hline Öğretmen aday1 & 1 & 1,9 \\
\hline İlkokul & 2 & 3,7 \\
\hline İlköğretim-öğretmen- yönetici & 3 & 5,6 \\
\hline Lise-öğrenci & 5 & 9,3 \\
\hline İlköğretim-öğrenci-öğretmen & 4 & 7,4 \\
\hline Yuva-öğrenci & 1 & 1,9 \\
\hline İlköğretim-öğretmen & 3 & 5,6 \\
\hline Üniversite-öğrenci & 2 & 3,7 \\
\hline Anasinifi-öğrenci & 1 & 1,9 \\
\hline Üniversite-öğretim elemanı & 2 & 3,7 \\
\hline
\end{tabular}

Tablo 3’teki örneklem grupları dikkate alındığında, daha çok ilkokul kademesinde ve öğrenci odaklı çalışmalar yapıldığı gözlemlenmiştir. Bu alanda yapılmış çalışmaların \%51,9’unu ilköğretim öğrencileri oluştururken, öğretmenler örneklemin \%27,9’unu oluşturmaktadır. Lise kademesinde yer alan öğrenciler ise örneklemin \%9,3’ünü oluşturmaktadır. Bu bilgiler ışığında değerler eğitimi üzerine yapılan doktora tezlerinin daha farklı örneklem gruplarıyla ve tüm bileşenleriyle yapılması daha yararlı olacaktır. Değer eğitiminde önemli bir yeri olan ebeveynlerin örneklem olarak çok fazla alınmaması dikkat çekici bir durumdur. Değer eğitiminde yine önemli bir yeri olan okul yöneticilerinin az olması eksiklik olarak söylenebilir. Değer eğitiminin tüm bileşenlerini göz önünde bulundurduğumuzda okul, aile ve çevre üçgeni önem arz etmektedir. Bu boyutların herhangi birinin eksik olması değer eğitiminin niteliğini etkileyebilir.

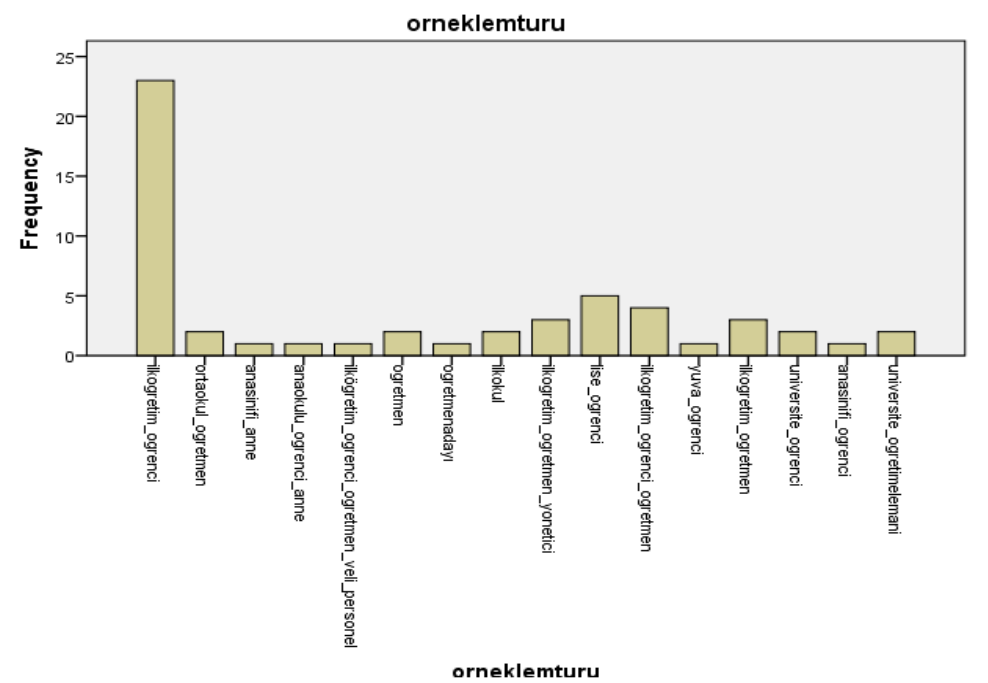

Şekil 3. Değer eğitimi ile ilgili doktora tezlerinin örneklem türüne göre dağılımı

Tablo 4. Değer Eğitimi Alanında 2000-2015 Yılları Arasında Yapılan Doktora Tezlerinin Örneklem Büyüklügüne Göre Dağllımı

\begin{tabular}{lrr}
\hline Örneklem say1s1 & Frekans & Yüzde \\
\hline $0-100$ & 20 & 37,0 \\
\hline $101-500$ & 13 & 24,1 \\
\hline $501+$ & 19 & 35,2 \\
\hline
\end{tabular}

Tablo 4' de örneklem büyüklükleri için üç değer aralığı tanımlanmıştır. Bu aralıklar 0-100, 101-500 ve $501+$ olarak seçilmiştir. Tabloda örneklem büyüklüklerinin $0-100$ ve $501+$ aralıklarında kümelendiği görülmektedir. 0-100 aralığında yapılan 20 tez örneklemin \%37’sini oluşturmuştur. 501+ aralığında ise 19 tez yapılmış olup örneklemin \%35,2’ini oluşturmuştur. Belirli bir örneklem büyüklüğü ile diğerleri arasında büyük bir fark olmaması bize çalışmalarda örneklem büyüklüğünün ihtiyaca göre belirlendiğini göstermektedir. 


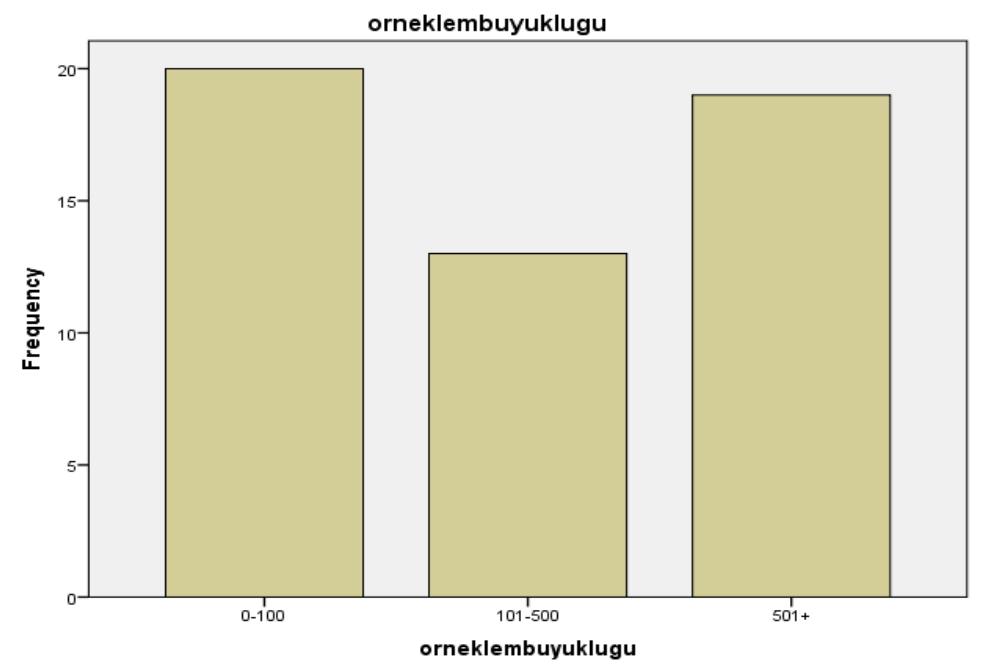

Şekil 4:Doktora tezlerinin örneklem büyüklügüne göre dağılımı

Tablo 5. Değer Eğitimi Alanında 2000-2015 Yilları Arasında Yapılan Doktora Tezlerinin Kullanılan Yönteme Göre Dağılımı

\begin{tabular}{lrr}
\hline Yöntem türü & Frekans & Yüzde \\
\hline Nitel & 18 & 33,3 \\
\hline Nicel & 13 & 24,1 \\
\hline Karma & 23 & 42,6 \\
\hline
\end{tabular}

Tablo 5'de araştırma yöntemleri nitel ve nicel olmak üzere ikiye ayrılmış olmakla beraber, bazı çalışmalarda her ikisini de içeren karma yöntem üçüncü araştırma yöntemi olarak karşımıza çıkmaktadır. Tezlerde en çok karma yöntemin kullanıldığı görülmektedir. Karma yöntem örneklemin \%42,6'sını oluşturmuştur. Nitel yöntem ise örneklemin \%33,3’ünü, nicel yöntem ise örneklemin \%24,1 oluşturmaktadır. Karma yöntemin diğer iki yönteme göre daha çok kullanılması önem arz etmektedir. Bunun nedeni karma yöntemde araştırmanın birden fazla boyuta sahip olmasıdır. Nitel araştırmalarda nasıl ve niçin sorularına cevap aranırken, nicel araştırmalarda ise ne kadar sorusuna cevap aranmaktadır. Karma araştırmalar bu soruları birleştirdiği için daha bütüncül ve daha gerçekçi araştırmalar ortaya koymaktadır.

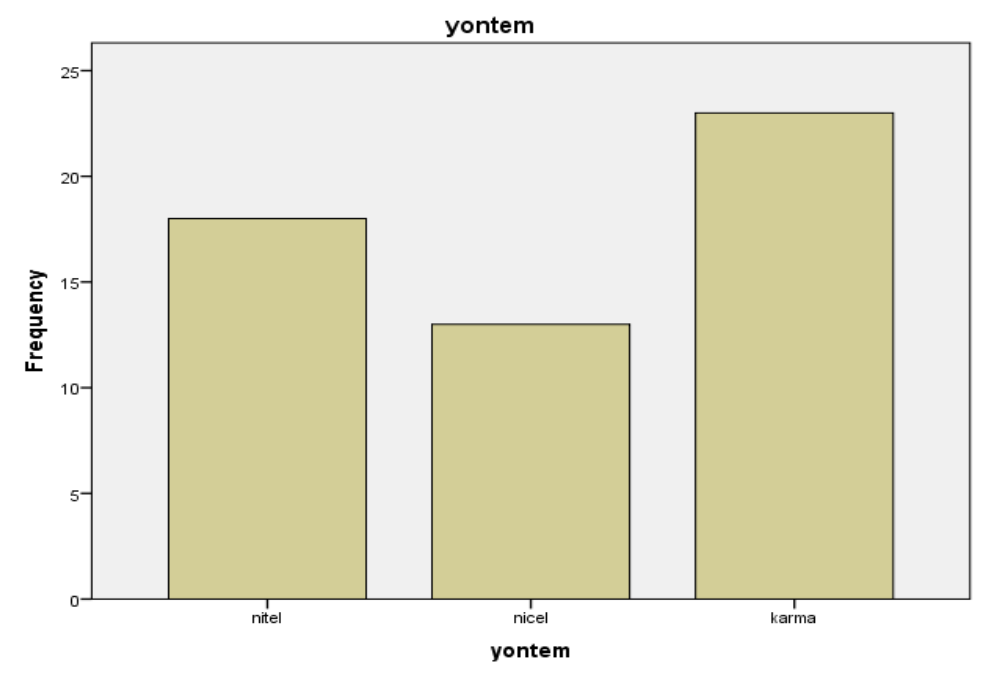

Şekil 5:Doktora tezlerinin kullanılan yönteme göre dağılımı

Tablo 6. Değer Eğitimi Üzerine 2000-2015 Y1llarında Yapılan Doktora Tezlerinin Konu Dağılımı

\begin{tabular}{lll}
\hline Konu Alanı & Frekans & Yüzde \\
\hline Değer türleri & 10 & 18,5 \\
\hline Doğrudan bir değer & 21 & 38,9 \\
\hline Programdaki değerler & 23 & 42,6 \\
\hline
\end{tabular}

Tablo 6'da değer eğitimi üzerine yapılan tezlerin konu alanlarının dağılımı; değer türü, doğrudan çalışlan değer ve öğretim programındaki değerler olmak üç kategori altında toplanmıştır. Tezlerde en çok öğretim programındaki değerler $(\% 42,6)$ ve doğrudan bir değer alanı $(\% 38,9)$ çalışılmıştır. Programdaki değerlere baktığımızda en çok karakter eğitimi, demokrasi eğitimi, insan hakları, vatandaşlık, duyuşsal amaçlar ve değer 
öğretimi gibi konuların yer aldığ1 görülmüştür. Bu konular öğretim programının öğrencilere vermeye çalıştı̆̆1 değerlerin sorgulanması ve kazanılabilirliği açısından önemlidir. Nitekim değer eğitiminin önemsenmesi kadar yer aldığ1 programdaki sunuluş biçimi de önem arz etmektedir.

Doğrudan bir değer olarak çalışlan tezlere baktığımızda ise, sorumluluk değerinin bariz bir şekilde diğerlerinden fazla olduğu görülmüştür (6 tezde). Empati, yardımseverlik, hoşgörü, temizlik, özgüven, savaş ve barış, demokratiklik ve adalet gibi değerlerin de çalışıldığ tespit edilmiştir. Bu durum sadece öğretim programlarının etkililiği ve programda bulunan değerlerin yanında, doğrudan bir değerin derinlemesine araştırıldığını göstermektedir. Yapılan ve yapılacak olan bu tarz spesifik araştırmalar, değerlere daha da anlam katması ve bilinmeyen yönlerin ortaya çıkarılması açısından önemlidir.

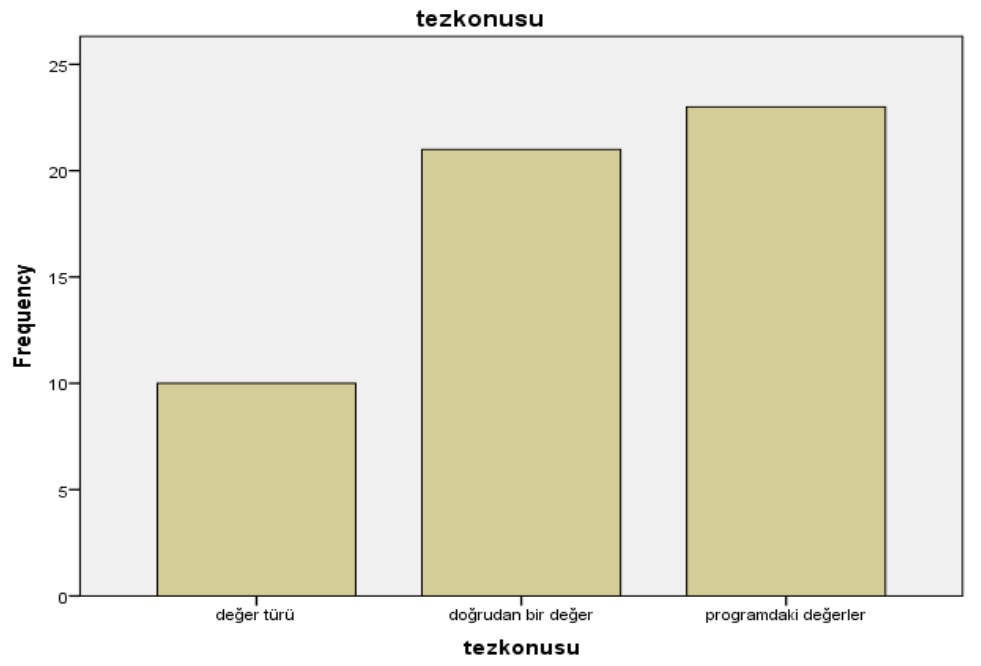

Şekil 6:Doktora tezlerinin konu alanına göre dağılımı

Tablo 7. Değer Eğitimi Üzerine 2000-2015 Yıllarında Yapılan Doktora Tezlerinin Veri Toplama Araçlarının Dağılımı

\begin{tabular}{lll}
\hline Veri toplama arac1 & Frekans & Yüzde \\
\hline Envanter & 1 & 1,0 \\
\hline Senaryo & 1 & 1,0 \\
\hline Video & 2 & 2,0 \\
\hline Günlük & 2 & 2,0 \\
\hline Gözlem & 3 & 3,1 \\
\hline Anket & 8 & 8,2 \\
\hline Görüşme & 9 & 9,2 \\
\hline Test & 14 & 14,3 \\
\hline Görüşme formu & 23 & 23,5 \\
\hline Ölçek & 35 & 35,7 \\
\hline
\end{tabular}

Tablo 7'de değer eğitimi üzerine yapılan doktora tezlerinde kullanılan veri toplama araçları yer almaktadır. Bu tablo oluşturulurken diğer tablolardan farklı olarak tezlerde kullanılan veri toplama araçları, tez başına değil bir tezdeki tüm araçlar tek tek çıkarılarak tespit edilmiştir. Tabloya göre tezlerde araştırmacıların en fazla ölçek ve görüşme formu kullandığ1 tespit edilmiştir. Özellikle veri toplama aracı olarak 54 tezden 35'inde ölçek kullanılması oldukça yüksek bir orandır. Ölçeğin kullanıldığ1 tezlerin çoğunda da buna ek olarak görüşme formunun kullanıldığ1 görülmüştür (23 tezde). Bu araçlar araştırmanın niteliği açısından önem arz etmektedir. Çünkü duyuşsal alan içerisinde yer alan değerlerin sadece tek bir araçla ve özelliklede nicel bir araçla ölçülmeye çalışılması tartışma yaratabilir. Bunun nitel veri toplama aracı olan görüşme formuyla desteklenmesi verilerin güvenirliği açısından önemlidir. Ancak görüşmeden ziyade görüşme formunun kullanılması ve yeterince gözlem yapılmaması tartışmalı bir durumdur. Değer gibi uzun sürede oluşan ve kalıcılığı davranışlara belli bir süre sonra yansıyan bir amacı, kısa vadeli araçlarla ölçmeye çalışmamız, değerlerin yeterince anlaşılmadığı veya gereken nitelikli araştırmaların halen az olduğu sonucunu doğurabilir. 


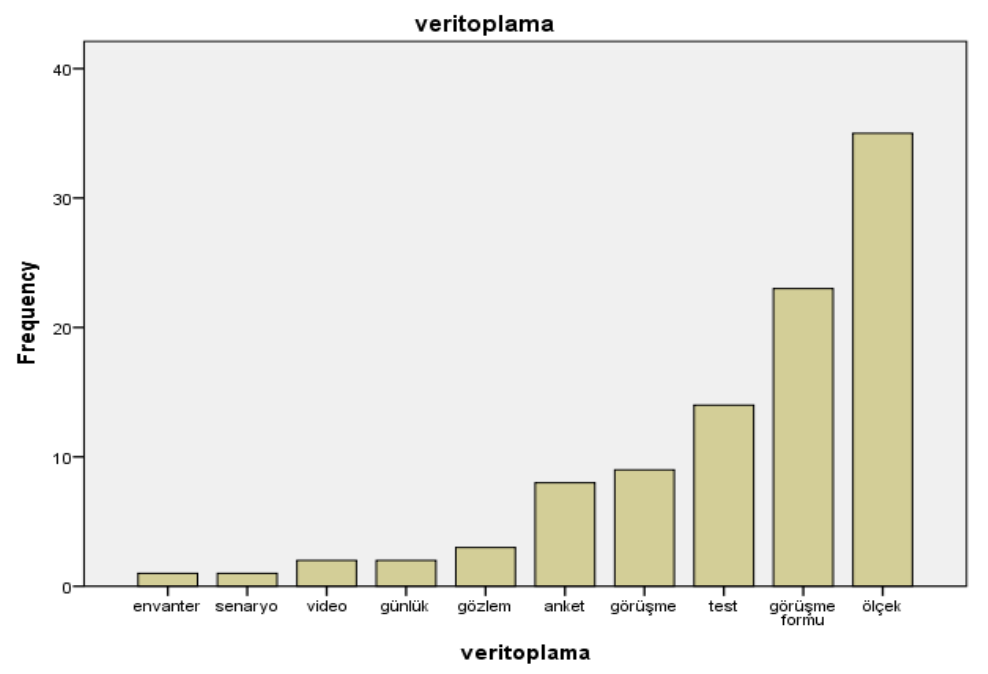

Şekil 7. Doktora tezlerinin veri toplama aracına göre dağılımı

Tablo 8. Değer Eğitimi Üzerine 2000-2015 Y1llarında Yapılan Doktora Tezlerinin Veri Analiz Yöntemlerinin Dağılımı

\begin{tabular}{lll}
\hline Veri Analiz Çeşidi & Frekans & Yüzde \\
\hline Nitel analiz & 5 & 9,3 \\
\hline Nicel analiz & 22 & 40,7 \\
\hline Hem nitel hem Nicel analiz & 27 & 50,0 \\
\hline
\end{tabular}

Tablo 8'de değer eğitimi üzerine yapılan doktora tezlerinde kullanılan veri analiz yöntemleri yer almaktadır. Tabloda nitel analiz olarak betimsel ve içerik analizi esas alınmıştır. Nicel analiz olarak ise frekans, yüzde, ortalama, standart sapma, t testi, anova, regrasyon, kruskal wallis, mann whitney u, ki kare ve faktör analizi gibi yöntemler incelenmiştir. Tabloya bakıldığında hem nitel hem nicel analizlerin birlikte kullanıldığı tezlerin daha çok olduğu görülmektedir. Bu durum değerlerin bütün olarak ele alınmasının daha anlamlı sonuçlar doğuracağına işaret etmektedir. Çoğu tezde önceki tablolarda da belirtildiği gibi yöntem olarak karma yöntemin kullanılması, veri toplama aracı olarak hem nitel hem nicel araçların bir arada olması ve analiz anlamında da ikisinin bir arada olması olumlu bir özellik olarak değerlendirilebilir. Çünkü değerler eğitimi alanını daha derin inceleyebilmek için bu tür araştırmalara ihtiyaç vardır.

Nicel veri analizi olarak en fazla $\mathrm{t}$ testi (27 tezde) veya nonparametrik karşıllı̆̆ mann whitney u'nun kullanıldığı, ikinci sırada ise varyans analizi (anova) veya nonparametrik karşıllı̆ı kruskal wallis’in (20 tezde) kullanıldığ1 tespit edilmiştir. Bu da nicel veri analizinde tezlerde daha çok basit istatistiki işlemlerin yapıldığı, diğer bir deyişle çok değişkenli istatistiklerin fazla kullanılmadığı görülmüştür. Derinlemesine analiz yapabilmek için diğer çok yönlü istatistiklere de ihtiyaç duyulmaktadır. Nitel veri analizi olarak ise en çok içerik analizi (20 tezde) kullanılmıştır. İçerik analizinin betimsel analize göre daha çok tercih edilmesi ise nitel boyutta var olan kavramları açıklamak yerine yeni kavramlar ve temalar oluşturması açısından önemlidir.

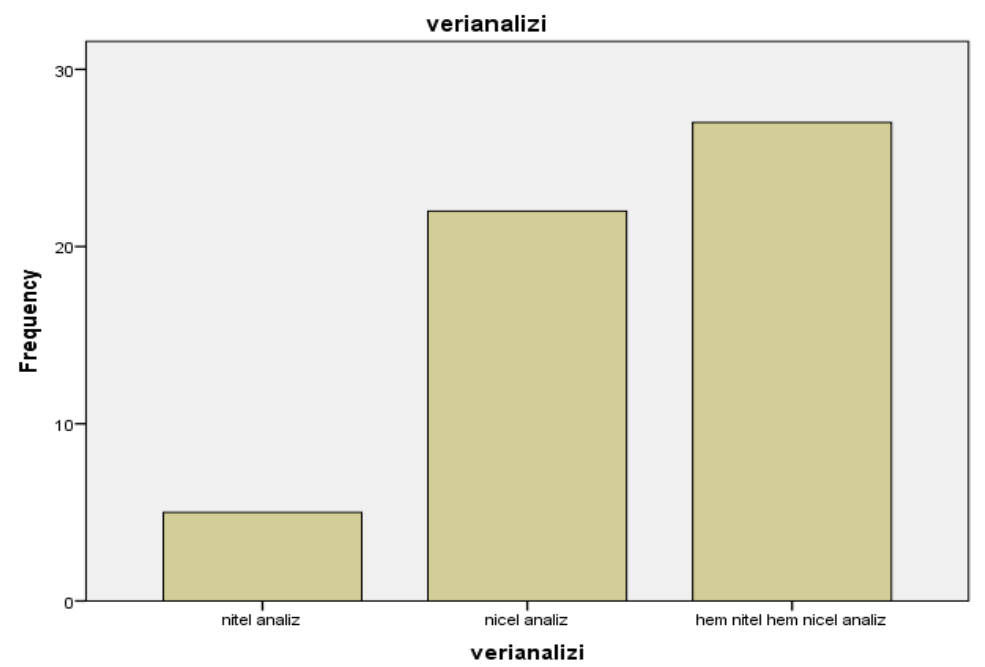

Şekil 8. Doktora tezlerinin veri analiz yöntemine göre dağglımı 


\section{TARTIŞMA ve SONUÇ}

$\mathrm{Bu}$ çalışmada, değer eğitimi üzerine yapılan doktora tezleri çeşitli açılardan içerik analizi yapılarak incelenmiştir. İncelemeler yapılırken, tezin kimliği hakkında tanımlayıcı bilgi, konusu, yöntemi, örneklemi, veri toplama aracı ve veri analiz yöntemi şeklindeki sorulara cevap aranmıştır. Çalışmada her bir araştırma sorusuna yönelik bulgular tek tek ele alınarak tartışılmış ve önerilerde bulunulmuştur.

Bulgular kısmındaki tablo 1 ve tablo 2'de görülebileceği üzere, Türkiye'de değer eğitimi üzerine yapılan doktora tezleri son ylllarda artmaya başlasa da henüz istenilen seviyede değildir. Değerler eğitimi, Türkiye'de yeni çalışılmaya başlanmış ve gittikçe daha çok ilgi duyulan bir alan olarak karşımıza çıkmaktadır. Elbir ve Bağc1 (2013) tarafından yapılan "Değerler eğitimi üzerine yapılmış lisansüstü düzeyindeki çalışmaların değerlendirilmesi” isimli araştırmada değerler üzerine yapılan tezlerin büyük bir kısmının yüksek lisans tezi olduğu tespit edilmiştir. Doktora tezleri açısından ise değer eğitimi üzerine yapılan araştırmalara bakıldığında yeterli olmadığı görülmektedir.

Örneklem olarak ise daha çok ilköğretim kademesindeki öğrenciler alınmıştır. Güçlü (2015) tarafından yapılan “Türkiye'de değerler eğitimi konusunda yapılan araştırmalar” isimli araştırmada da benzer bir sonuç bulunmuştur. Değer eğitimi araştırmalarında örneklem olarak küçük yaştaki bireylerin alınması, değer eğitiminin küçük yaşlarda başlaması gerektiğini ön plana çıkarmaktadır. Çocuklar bu dönemde içinde bulundukları gelişim dönemi gereği yön verilmeye ve değerlerin oluşmaya başladığı yaşlardadır. Bu nedenle nitelikli bir değer eğitimi için bilhassa sınıf öğretmenlerine önemli görevler düşmektedir. Eğitim bilimlerinde yapılan çalışmalar göstermektedir ki öğretmenlerin yeterlilikleri (kişisel ve mesleki) arttıkça daha nitelikli ve karakterli öğrenciler yetişebilmektedir (Gözütok, 1995; Gürkan, 1993; Mentiş Taş, 2004). Bu nedenle ilköğretim öğrencilerinin ileride başarılı ve karakterli olmaları onların sınıf öğretmenlerini çok sevmelerine bağlıdır (Demirel, 2011). Karşıdaki kitle çok küçükse ve biz onlara bir şeyler öğretmeyi planlıyorsak, öncelikle bilgiden ziyade karakterimizle onları etkilememiz gerekir (Erden, 2008; Cihan, 2014)). Özellikle küçük yaştaki bireyler ve öğrenciler için, öğretici pozisyonunda bulunan kişide, mesleki becerilerden daha çok kişisel özelliklerin önemli olduğu anlaşılmışırır (Yarar ve Tekbıyık, 2009).

Yöntem olarak ise tezlerde daha çok karma yöntem kullanılmıştır. Bu durum tezlerin amaca ulaşması noktasında isabetli bir durum oluşturmuştur. Çünkü değer eğitimi duyuşsal alan ağırlıklı olduğu için sadece nicel araştırma yöntemleri kullanılsaydı tartışma konusu olabilirdi. Karma yöntemde, hem nitel hem de nicel yöntemler beraber kullanılırsa, gerçekliğe ilişkin daha sağlıklı ve çoğulcu verilere ulaşmak kolaylaşır. Nicel yöntemler genelde sayısal veriler toplamakta, bunları karşılaştırmakta ve aralarındaki farklılıkların anlamlı olup olmadığını ortaya çıarmaktadır. Nitel yöntemlerde ise bağlamsal nitelikte veriler toplanmakta ve alternatif bakış açılarına dayalı yorumlardan yararlanılmaktadır. Böylece, nicel ve nitel yöntemler, aynı araştırmada birbirini güçlendirecek biçimde kullanılır.

Veri toplama aracı olarak tezlerde ağırlıklı olarak ölçek kullanılmış ve nitel araştırma yönteminde çok kullanılan görüşme formuyla desteklenmiştir. Bu durum da yöntem olarak karma yöntemin tercih edilmesinin doğal bir sonucudur. Nitekim karma yöntemin kullanıldığı tezlerde hem nitel hem nicel veri toplamak için birden fazla ölçme aracına ihtiyaç duyulmuştur. Veri toplama aracı olarak daha çok ölçek kullanılması duyuşsal alandaki kazanımların ölçülebilirliği açısından önem arz etmektedir. Nitel veri toplama aracı olarak ise görüşme formunun, bire bir görüşme yerine daha çok tercih edilmesi tezleri nitelik açısından sorgulamamıza götürebilir. Çünkü daha çok örneklem olarak ilköğretim öğrencilerinin bilhassa ilkokul kademesindeki öğrencilerin olduğu bir araştırmada, veri toplanırken çocukların duygularını forma yansıtması biraz zor olabilmektedir. Bunun yerine bire bir görüşme yapılarak daha güvenilir sonuçlar elde edilebilinir. Toplanan verilerin analizinde kullanılan yöntem doğrultusunda, daha çok hem nitel veri hem de nicel veri analizleri birlikte kullanılmıştır. Bu durum duyuşsal alanın doğası gereği olumlu bir özellik olarak sayılabilinir. Değer eğitimi üzerine yapılan doktora tezlerinin çoğunda; yöntem, veri toplama ve veri analizi açısından karma yöntemlerin birlikte kullanılması bu araştırmanın olumlu tespitleri arasında yer almıştır. Nitel veri analizinde daha çok içerik analizi 
yapılarak yeni anlamlar oluşturmaya çalışmak olumlu bir özellik iken; nicel verilerin analizinde ise daha çok t testi ve anova (nonparametrik karşılıkları da dahil) kullanılması biraz daha derin analiz yapılması yönünde eksik kalmıştır.

Yapılan araştırmada elde edilen bulguların değer eğitimi araştırmacılarına, eğitimcilere ve araştırma yapmaya yeni başlayan genç akademisyenlere rehber olması öngörülmektedir. Değer eğitimi alanında çalışan ve bu alanda yayın yapan akademisyenler için geçmişten günümüze değerler eğitimi alanında kullanılan araştırma konularının, yöntemlerin, veri analiz yöntemlerinin bilinmesi yeni yapılacak olan çalışmalara 1şık tutması açısından önemlidir. Ayrıca değer eğitimi alanında yapılan doktora tezlerine içerik analizi yapılmasıyla da bu alanla ilgilenen tüm araştırmacıları yeniliklere yöneltmesi beklenmektedir. Bu araştırma bulguları sayesinde de gittikçe artan bir öneme sahip olan değerler eğitimi konusunu bütün olarak görmek mümkün olacaktır.

Sonuç olarak bu araştırma göstermiştir ki değer eğitimi üzerine yapılan doktora tezleri az olmakla birlikte gittikçe daha çok önem verilen bir alan haline gelmeye başlamıştır. Araştırmada elde edilen bulgular neticesinde, yeni yapılacak çalışmalar alanda eksik görülen yerleri dolduracak şekilde olursa, bu alanın daha da gelişeceği düşünülmektedir. Bu bağlamda aşağıdaki önerilere yer verilmiştir:

\section{5. Öneriler}

- Yapılan doktora tezlerinde sabır, vicdan, hoşgörü, vatanseverlik, merhamet, adalet, güven, gibi değerler fazla çalışılmamış iken sorumluluk, yardımseverlik, empati, demokratik değerler, kültürel değerler gibi konulara daha fazla yer verilmiştir. Bu yüzden farklı değerler üzerinde de araştırmalar yapilmalidir.

- Ayrıca yapılan çalışmalar daha çok ilkokul düzeyinde ve sadece öğrencilere yöneliktir. Diğer kademelerle de çalışılmalı ve değer eğitiminin diğer bileşenleri olan öğretmen, yönetici ve veliler de çalışmalara dahil edilmelidir.

- Başka bir boyutta değer gibi uzun sürede kazanılan bir olgunun genellikle yapılan çalısmalarda kısa sürede yapılarak sonuç elde edilmeye çalışılmasıdır. Bu bağlamda boylamsal çalışmalara ihtiyaç vardır.

- Değer eğitimi üzerine yapılan tezler daha çok yüksek lisans düzeyinde olduğu için yapılan bu çalışma ile doktora tezlerinin azlığına dikkat çekilmiş ve bundan sonraki araştırmacılara yol gösterici olması beklenmektedir. 


\section{KAYNAKÇA}

Acat, M. B. ve Aslan, M.(2012). Yeni Bir Değer Sınıflaması ve Bu Sınıflamaya Bağlı Olarak Öğrencilere Kazandırılması Gereken Değerler, Kuram ve Uygulamada Eğitim Bilimleri, 12(2), 1460-1474.

Ada, S., Baysal, Z. N. ve Korucu, S. (2005). Sınıf Öğretmenlerinin Sınıf İçi Olumsuz Davranışlara Gösterdikleri Tepkilerin Karakter Eğitimi ve 2005 İlköğretim Programı Açısından Değerlendirilmesi, Değerler Ë̆gitimi Dergisi, 3(10), 7-18.

Akarsu, S. (2015). İlkokul (14) ve Ortaokul (5-8) Müzik Ders Kitaplarnda Yer Alan Şarkılarn Değerler Bakımından Incelenmesi ve Değerler Eğitimine İlişkin Ögrenci Algzlar. (Yayınlanmamış doktora tezi). Yüzüncü Yıl Üniversitesi, Eğitim Bilimleri Enstitüsü,Van

Akbaş, O.(2004). Türk milli eğitim sisteminin duyussal amaçlarnmn ilkëğgretim II. kademedeki gerçekleşme derecesinin değerlendirilmesi. (Yayınlanmamış doktora tezi). Gazi Üniversitesi, Eğitim Bilimleri Enstitüsü, Ankara

Aladağ, S. (2009). İlköğretim sosyal bilgiler ögrretiminde değer eğitimi yaklaşmlarmm ögrencilerin sorumluluk değerini kazanma düreyine etkisi. (Yayınlanmamıs doktora tezi). Gazi Üniversitesi, Eğitim Bilimler Enstitüsü, Ankara

Baysal, N (2013). Ortaokul Sosyal Bilgiler Derslerinde Değerler Eitimi Uygulamalarnnn Öğretmenler Yönüyle Değerlendirilmesi, (Yayınlanmamış Yüksek Lisans Tezi). Niğde Üniversitesi, Eğitim Bilimleri Enstitüsü, Niğde

Bilgin, N. (1995). Sosyal Psikolojide Yöntem ve Pratik Çalısmalar. İstanbul: Sistem Yayınc1lık.

Bolay, S. H. (2013). Felsefe Doktrinleri ve Terimleri Sö̧lüğ̈̈, Ankara, Nobel Yayıncilı.

Bryk, A and Schneider, B. (2002).Trust in Schools: A Core Resource for Improvement, New York: Russell Sage Foundation

Büyüköztürk, Ş., Çakmak, E. K., Akgün, Ö. E., Karadeniz, Ş. ve Demirel, F. (2009). Bilimsel Araștırma Yöntemleri. Ankara: Pegem Yayıncilik.

Canatan, K. (2004). Avrupa Birliği Ülkelerinde Değerler Yönelimi, Değerler Ĕ̈̆timi Dergisi, 2(7-8), 41-63.

Cihan, N. (2014). Okullarda Değerler Eğitimi ve Türkiye'deki Uygulamaya Bir Bakış. Electronic Turkish Studies, 9(2), 429-436.

Creswell, J. W. (2005). Educational research: planning, conducting and evaluating quantitative and qualitative research (2. bs.). USA: Pearson Prentice Hall.

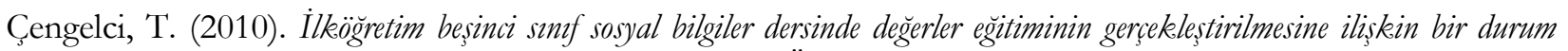
çalıșması. (Yayınlanmamış doktora tezi). Anadolu Üniversitesi, Eğitim Bilimleri Enstitüsü, Eskişehir

Demirel, Ö. (2011). Ögrretim İlke ve Yöntemleri Ögretme Sanat, Ankara: Pegem A Yayıncilık.

Dilmaç, B. (2007). Bir grup fen lisesi ögrrencisine verilen insani değerler eğitiminin insani değerler ölçĕgi ile sinanmasi. (Yayınlanmamış doktora tezi). Selçuk Üniversitesi, Sosyal Bilimler Enstitüsü, Konya

Ekşi, H. ve Katılmış, A. (2011). Karakter Ĕgitimi El Kitabı, Ankara, Nobel Yayıncılık.

Elbir, B. ve Bağc1, C.(2013). Değerler eğitimi üzerine yapılmış lisansüstü düzeyindeki çalışmaların değerlendirilmesi, Turkish Studies - International Periodical for the Languages, Literature and History of Turkish or Turkic ,8(1),1321-1333.

Ercan, İ. (2001). İlkögrretim Sosyal Bilgiler Programında Ulusal ve Evrensel Değerler. (Yayınlanmamış Yüksek Lisans Tezi). Onsekiz Mart Üniversitesi, Sosyal Bilimler Enstitüsü, Çanakkale

Erden, M. (2008). Sinıf Yönetimi, Ankara: Arkadaş Yayınları.

Glass, G. V. (1976). Primary, secondary, and meta-analysis of research. Educational Researcher, 5(10), 3-8.

Glass, G. V. (1982). Meta-analysis: An approach to the synthesis of research results. Journal of Research in Science Teaching, 19(2), 93-112.

Glass, G. V., McGaw, B., \& Smith, M. L. (1981). Meta-analysis in social research. Beverly Hills, CA: Sage.

Gözütok, F. D. (1995). Ögrretmenlerin Demokratik Tutumlar, Ankara: Ekin Yayınc1lık.

Güçlü, M. (2015). Türkiye'de değerler eğitimi konusunda yapılan araştırmalar, Uluslararası Sosyal Araştırmalar Dergisi, 8(38), 720-732

Gündüz, M. (2014). İlkögretim 3. smif hayat bilgisi dersinde "sorumluluk" değerinin proje tabanl ögrenme yaklasım ile ögretiminin akademik başar ve tutuma etkisi. (Yayınlanmamıs doktora tezi). Gazi Üniversitesi, Eğitim Bilimleri Enstitüsü, Ankara). https:/ / tez.yok.gov.tr/UlusalTezMerkezi/ adresinden edinilmiştir.

Gündüz, M.(2016). Classifying Values by Categories, Journal of Education and Training Studies, 4 (10), 212- 220 (ERIC), http://dx.doi.org/10.11114/jets.v4i10.1765

Güngör, E. (1998). Ahlak psikolojisi ve sosyal ablak. İstanbul: Ötüken Yayınevi.

Gürkan, T. (1993). İlkokul Ögretmenlerinin Ögrretmenlik Tutumlar İle Benlik Kavramlar Arasindaki İlişki, Ankara: Sevinç Matbaası. 
Kale, N.(2004). Nasıl Bir Değerler Eğitimi, Değerler ve Eğitimi Uluslararası Semposynumu, İstanbul: Değerler Eğitimi Merkezi Yayınları

Kantar, Ş. (2014). İlköğretim 4 ve 5. Simf Sosyal Bilgiler Dersinde 100 Temel Eser Yoluyla Değerler Eğitimi, (Yayınlanmamış Yüksek Lisans Tezi), Necmettin Erbakan Üniversitesi, Eğitim Bilimleri Enstitüsü, Konya

Keskin, Y. (2008). Türkive’de Sosyal Bilgiler Öğretim Programlarnda Değerler Ĕ̈̆timi: Taribsel Gelișim, 1998 ve 2004 Programlarmm Etkililiğinin Arastırlması. (Yayınlanmamış doktora tezi). Marmara Üniversitesi, Eğitim Bilimleri Enstitüsü, İstanbul

Keskinoğlu, M.Ş. (2008). İlköğretim Beşinci Sme Öğrencilerine Uygulanan Mesnevi Temelli Değerler Eğitimi Programmmn Ablaki Olgunluğa ve Saldrrganllk Eğilimine Etkisi. (Yayınlanmamış Yüksek Lisans Tezi). Yeditepe Üniversitesi, İstanbul

Lickona, T. (1991). Educating for Character. Bantam Boks, New York.

Lovat, T. (2007). Values Education: The Missing Link in Quality Teaching and Effective Learning, D.N. Aspin and J.D. Chapman (eds.), V alues Education and Lifelong Learning, pp. 199-210

Meaney, M. H. (1979). A Guide for Implementing Values Education in the Primary Grades. Unpublished Doctor's Thesis, Seattle University. Seattle, Washington.

Mentiş Taş, A. (2004). "Sosyal Bilgiler Öğretmenliği Eğitimi Program Standartlarının Belirlenmesi”, Eğitim Bilimleri Fakültesi Dergisi, 37(1), 28-51.

Miles, M.B and Huberman, A.M. 1994. Qualitative dataanalysis,Thousand Oaks, CA: Sage.

Naylor, D., \& Diem, R. (1987). Elementary and middle school social studies. New York: Random House.

Öncül, R. (2000). Eğitim ve Eğitim Bilimleri Sözlüğ̈̈, İstanbul: Milli Eğitim Basımevi.

Özdaș, F. (2013). Ortaokullarda Değerler Ë̆̈itimi ve İstenmeyen Öğrenci Davranıslarnna İlișkin Öğretmen Görüslerinin Değerlendirilmesi, (Yayınlanmamış Yüksek Lisans Tezi), Fırat Üniversitesi Sosyal Bilimler Enstitüsü, Elazığ

Özensel, E. (2003).“Sosyolojik Bir Olgu Olarak Değer”, Değerler Eğitimi Dergisi,1(3): 217 - 239

Özsoy, S. (2007). Değerlere Dayalı Bir Ortam Yaratmak Eşittir Daha İyi Bir Dünya Yaratmak, İlk Öğretmen Dergisi, 14, 30-34

Refshauge, H.A. (2004). Values in NSW Public Schools, Retrieved from www.schools.nsw.edu.au.

Rokeach, M. (1973). The Nature of Human Values. New York: Free Pres

Schwartz, S. H. (1992). Universals in the content and structure of values: Theoretical advances and emprical tests in 20 countries. Advances in Experimental Social Psychology, 25, 1-65.

Snook, I. (2007). Values Education in Context. D.N. Aspin and J.D. Chapman (eds.), Values Education and Lifelong Learning

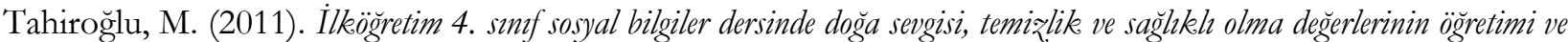
değerlere iliş̧kin ögrenci tutumlarnm belirlenmesi. (Yayınlanmamış Doktora tezi). Gazi Üniversitesi, Eğitim Bilimleri Enstitüsü, Ankara

Tillman, D.(2000). Living Values Activities for Young Adults. Deerfield Beach-Florida: Health Communications Inc.

Ulusoy, K. (2007). Lise tarih programmda yer alan geleneksel ve demokratik değerlere yönelik ögrenci tutumlarmn ve görïslerinin çeşitli değ̈̌şkenler açısından değerlendirilmesi. (Yayınlanmamış Doktora tezi). Gazi Üniversitesi, Eğitim Bilimleri Enstitüsü, Ankara

Ülger, M. (2012). Illköğretim okullarnda insan haklar vatandaşlı eğitimi uygulamalarmnn değerlendirilmesi. (Yayınlanmamış doktora tezi). Gazi Üniversitesi, Eğitim Bilimleri Enstitüsü, Ankara

Yarar, S. ve Tekbıyık, A. (2009). "Öğretmen Adaylarmm Öğretmenlik Mesleğine Yönelik Sabip Olduklar Kișisel ve Mesleki Nitelikler Konusundaki Alg̨larnnn İncelenmesi”, I. Uluslar Arası Eğitim Araştırmaları Konferans1, On sekiz Mart Üniversitesi, Mayıs, Çanakkale.

Yıldırım, A. ve Şimşek, H. (2006). Sosyal bilimlerde nitel araștırma yöntemleri. Ankara: Seçkin Yayıncılık.

Yiğittir, S.(2009). İlkögretim 4.ve 5.sinnf sosyal bilgiler dersi değerlerinin kazanılma düzeyi. (Yayınlanmamış doktora tezi). Gazi Üniversitesi, Eğitim Bilimleri Enstitüsü, Ankara.

\section{Citation Information}

Gündüz, M., Başpınar, Z. \& Büyükkarcı, A. (2017). 2000-2015 Yllları Arasında Değer Eğitimi Üzerine Yapılan

Doktora Tezlerinin İçerik Analizi. Dicle Üniversitesi Ziya Gökalp Eğitim Fakültesi Dergisi, 31, 705-718. 
Mevlüt GÜNDÜZ, Zuhal BAŞPINAR \& Ayşegül BÜYÜKKARCI

Ek 1:Yayın Sinıflama Formu

\begin{tabular}{|c|c|c|c|c|c|c|c|c|c|c|c|c|c|c|c|c|c|}
\hline \multicolumn{18}{|l|}{$\begin{array}{l}\text { Tezin Adı } \\
\text { Hangi } \\
\text { Üniversitede } \\
\text { Yapildığ1 }\end{array}$} \\
\hline \multicolumn{18}{|l|}{$\begin{array}{l}\text { Kaç Yllnda } \\
\text { Yapildığ1 }\end{array}$} \\
\hline \multirow[t]{2}{*}{ Örneklem Türü } & \multicolumn{6}{|c|}{ Öğrenci } & \multicolumn{7}{|c|}{ Ögretmen } & \multicolumn{2}{|c|}{ Veli } & \multirow{2}{*}{$\begin{array}{c}\text { Yöneti } \\
\mathrm{ci}\end{array}$} & Öğgretim \\
\hline & \begin{tabular}{l|l}
$\mathrm{Y}$ & \\
$\mathrm{u}$ & \\
$\mathrm{v}$ & \\
$\mathrm{a}$ &
\end{tabular} & $\begin{array}{l}\text { Anaoku } \\
\text { lu }\end{array}$ & $\begin{array}{l}\text { illkok } \\
\text { ul }\end{array}$ & $\begin{array}{l}\text { Ortaok } \\
\text { ul }\end{array}$ & $\begin{array}{l}\text { Lis } \\
\mathrm{e}^{2}\end{array}$ & $\begin{array}{l}\text { Üniversi } \\
\text { te }\end{array}$ & $\begin{array}{l}\text { Yuv } \\
\text { a }\end{array}$ & $\begin{array}{l}\text { Anaoku } \\
\text { lu }\end{array}$ & $\begin{array}{l}\text { İlkok } \\
\text { ul }\end{array}$ & $\begin{array}{l}\text { Ortaok } \\
\text { ul }\end{array}$ & Lis & & versite & Anne & Baba & & \\
\hline Örneklem Sayis1 & \multicolumn{6}{|c|}{$0-100$} & \multicolumn{7}{|c|}{$101-500$} & \multicolumn{4}{|c|}{$501+$} \\
\hline Yöntem Türü & \multicolumn{6}{|c|}{ Nitel } & \multicolumn{7}{|c|}{ Nicel } & \multicolumn{4}{|c|}{ Karma } \\
\hline Konu Dağlımı & \multicolumn{6}{|c|}{ Değer türleri } & \multicolumn{7}{|c|}{ Doğrudan bir değer } & \multicolumn{4}{|c|}{ Programdaki değerler } \\
\hline $\begin{array}{l}\text { Veri Toplama } \\
\text { Arac1 }\end{array}$ & $\begin{array}{l}\text { Env } \\
\text { ante } \\
\mathrm{r}\end{array}$ & \multicolumn{2}{|c|}{ Ölçek } & \multicolumn{2}{|l|}{ Senaryo } & Test & \multicolumn{2}{|r|}{ Video } & \multicolumn{2}{|r|}{ Günlük } & & $\begin{array}{l}\text { Görüsmme } \\
\text { formu }\end{array}$ & $\begin{array}{l}\text { Gö } \\
\text { rüs } \\
\text { me }\end{array}$ & \multicolumn{2}{|c|}{ Gözlem } & \multicolumn{2}{|r|}{ Anket } \\
\hline Veri Analiz Türü & \multicolumn{6}{|c|}{ Nitel analiz } & \multicolumn{7}{|c|}{ Nicel analiz } & \multicolumn{4}{|c|}{ Hem nitel hem nicel analiz } \\
\hline
\end{tabular}

